\title{
Cross-Border Bean Market Performance in Western Kenya and Eastern Uganda
}

\author{
Lianda Wanyonyi Mauyo ${ }^{1}$, Jonas N. Chianu ${ }^{2}$, Bernard Kibet Nassiuma ${ }^{3}$, Richard Onyango Musebe ${ }^{4}$ \\ ${ }^{1}$ Masinde Muliro University of Science and Technology, Eldoret, Kenya; ${ }^{2}$ Tropical Soil Biology and Fertility institute of CIAT \\ (TSBF-CIAT), Nairobi, Kenya; ${ }^{3}$ Department of Quantitative Skills and Entrepreneurship Studies, Moi University, Eldoret, Kenya; \\ ${ }^{4}$ Department of Development Studies, Moi University, Eldoret, Kenya. \\ Email: lmauyo@yahoo.com
}

Received August 12 $2^{\text {th }}, 2010$; revised September $20^{\text {th }}, 2010$; accepted October $28^{\text {th }}, 2010$.

\begin{abstract}
Common bean (Phaseolus vulgaris) is an important grain legume in East Africa, providing food and income to rural households. Smallholder farmers in Kenya and Uganda have widely adopted improved varieties. The demand for common bean in Kenya outstrips domestic supply - hence the need for imports. There is significant border trade on common bean between Kenya and Uganda. This study assesses the efficiency of this trade and evaluates the performance of common bean marketing as well as the associated transport system. Purposive, multistage and systematic random sampling methods were used to select the 210 respondents for the study. SPSS was used for data analysis. Results indicate huge inefficiency in common bean marketing in Kenya and Uganda due to poor road infrastructure and high transaction costs (mostly due to transport costs). Primary market traders incurred a significantly higher cost than terminal market traders. Generally, Ugandan traders operated at relatively higher efficiency than Kenyan traders. However, all the traders made profits far in excess of their common bean transfer costs. The study recommends regional market, infrastructural, and institutional development as well as the abolition of illegal fees in order to improve bean market efficiency in the study area and similar environments.
\end{abstract}

Keywords: Bean, Cross-border Marketing, Marketing Costs, Market Performance, Government Levies

\section{Introduction}

Common bean (Phaseolus vulgaris) is a major food crop to people of all household income categories in many parts of sub-Saharan Africa, especially in Eastern Africa [1]. It is a major source of dietary protein and household cash income to the poor and small-scale farmers in Eastern and Southern Africa [2]. In Kenya, common bean is the most important pulse and second only to maize (Zea mays) as a food crop [3]. National annual demand for common bean in Kenya has been estimated at about 500,000 metric tons, as compared to annual domestic production, estimated at about 125,000 metric tons (or about $25 \%$ of domestic demand) [3]. The demand for common bean in Kenya is much more than local supply, which is then often supplemented with the imports, mostly from Uganda and Tanzania [2]. The total area cultivated to common bean in Kenya was estimated at 500,000 ha, leading to actual yield of $\sim 250 \mathrm{~kg} \mathrm{ha}^{-1}$, most often under intercropping or mixed cropping systems [3]. In pure stands (although not a common practice), yields of as high as $700 \mathrm{~kg} \mathrm{ha}^{-1}$ have been reported under farmer management conditions [3]. This is still low when compared with a yield potential of up to $5000 \mathrm{~kg} \mathrm{ha}^{-1}$ [4]. Such high yields have already been achieved in Mexico under field conditions [5]. Another estimate of Kenya's common bean deficit put it at about 200,000 metric tons [6]. The average annual official imports are 1,500 metric tons, while the annual imports not recorded by the customs authorities were estimated at about 9,300 metric tons [7]. This has resulted in a significant border trade on common bean between Kenya and Uganda [1].

The consumption of common bean in Eastern and Southern Africa exceeds $50 \mathrm{~kg}$ person ${ }^{-1}$ year $^{-1}$, reaching $66 \mathrm{~kg}$ person $^{-1}$ year $^{-1}$ in parts of Kisii district of Kenya [1]. Common bean contributes about 30\% of the dietary energy in Eastern and Southern Africa [8]. In Uganda, common bean is a popular and major source of food security. It is readily available for both urban and the rural populations. The consumption of common bean in Uganda was estimated at $\sim 29 \mathrm{~kg}_{\text {capita }^{-1}}$ annum $^{-1}$ [9]. 
More recent studies, however, show that per capita consumption of common bean in Nabongo area of Uganda was about $58 \mathrm{~kg}$ capita $^{-1}$ annum $^{-1}$ [10]. Common bean provides about $25 \%$ of total calories and about $45 \%$ of the proteins in the diet of many Ugandans [11]. Besides, it is an important source of income (from domestic demand and exports) to Uganda farm households [11]. In 1992, common bean ranked third in Uganda's crop export volume after coffee and cotton and fourth in the country's crop export value after coffee, cotton, and tobacco [2].

The poor rural road infrastructure results in inefficient common bean marketing system, hindering access to markets by the operators in the bean value chain in Eastern Africa. An efficient marketing system is an important means of raising the incomes of farm families and an important way of providing the dietary protein needs of the people of East Africa. Besides, such a system facilitates efficient allocation of production and consumption resources. Higher productivity is essential for the generation of surpluses for marketing within and across Eastern Africa. Hence the need to examine the market performance of common bean and to assess the transport status in the marketing of common bean in the border districts of Western Kenya and Eastern Uganda.

\section{Methodology}

\subsection{The Study Area}

This study was carried out in Bungoma and Busia districts of western Kenya and in Mbale and Kapchorwa districts of eastern Uganda. Bungoma district is one of the eight districts in the Western province of Kenya. In this study, the administrative boundaries of the lager Bungoma were used. Mixed farming system (crop and livestock) is the common practice in Bungoma district. Bungoma district soils are suitable for various types of crops including maize, finger millet, sorghum, upland rice, sweet potatoes, cassava, groundnuts, sesame, beans, coffee, sugarcane, cotton, sunflower and tobacco. Mean annual rainfall varies between $1250 \mathrm{~mm}$ to $1800 \mathrm{~mm}$. Bungoma has bimodal rainfall distribution. However, most farming activities occur during the long rains (peaking in April-May each year). Seasonal distribution of rainfall is $500-1000 \mathrm{~mm}$ during the long rainy season and $430-800 \mathrm{~mm}$ during the short rainy season (often with $60-70 \%$ reliability). Mean annual temperatures in Bungoma district varies from 21 to $25^{\circ} \mathrm{C}$. Bungoma district has good road and railway networks. These are important for farm produce transportation and marketing [12]. Like Bungoma, Busia district is one of the eight districts that form the Western province of Kenya. The administrative boundaries of the larger Busia district (in- cluding the present Teso district) were used. Again like in Bungoma district, farmers in Busia district commonly practice mixed farming. The district has 924,200 hectares (924 sq km) of agricultural. However, only 40,000 hectares (or $\sim 4.3 \%$ ) are under crop production. The rest are fallow lands (including bushes), swamps or bare land. Common farm sizes in Busia district range from 2 to 10 hectares. Like Bungoma district, Busia district has a bimodal rainfall distribution (long rains: March-June; short rains: August-October). The mean annual rainfall in Busia district is $1500 \mathrm{~mm}$ with most parts of the district receiving between $1270 \mathrm{~mm}$ and $1790 \mathrm{~mm}$. Annual mean maximum temperature ranges from 26 to $30^{\circ} \mathrm{C}$ while the annual mean minimum temperature ranges from 14 to $22^{\circ} \mathrm{C}$. The food crops commonly grown on small scale farms in Busia district include maize, cassava, sorghum, finger millet, common bean, groundnuts, and rice. The major cash crops grown in Busia district are sugarcane, cotton, tobacco, and coffee. Like Bungoma district, Busia district has good road networks for product transportation as well as several markets where common bean are marketed [13]. Mbale district, formerly known as Bugisu district, is in Uganda. It borders three Uganda districts (Kapchorwa in the Northeast, Tororo in the Southwest, and Kumi in the Northwest) and the Republic of Kenya (Western Kenya) in the East. Sironko district in Uganda was carved out from Mbale district, but for the purpose of this study, the administrative boundaries of the former larger Mbale (including Sironko) were used to define Mbale district [14]. Land ownership here is largely based on customary tenure system. Agriculture in Mbale district is mostly subsistence because of land shortage [14]. The altitude ranges from $1,299 \mathrm{~m}$ to $1,524 \mathrm{~m}$ above sea level with sub-tropical type of climate. Mbale district receives an average of 1,191 mm of rainfall per annum. Economic activities in Mbale district are mainly agriculture with emphasis on: food crops (common bean, maize, groundnut, sweet potatoes, cassava, bananas, soyabeans, sorghum, yams, and rice on a low scale), cash crops (coffee and cotton), and vegetables (tomatoes, onions, and cabbages). The district has enormous potential for tourism due to the existence of Mt. Elgon National park, Mt. Elgon-Sipi falls and the mountainous landscape. The highland terrain hinders modernisation of agriculture. Apart from hilly areas (where transportation is a problem during the rainy season), Mbale district has good road networks. It als has several markets for agricultural produce marketing [14]. Kapchorwa district is in Uganda and borders three Ugandan districts (Mbale in the south, Kumi in the west, and Moroto in the north) and Republic of Kenya (West Kenya) in the east [14]. Most farmers here practice mixed farming. Land tenure is customary and land has been greatly fragmented. Kapchorwa dis- 
trict soils are suitable for production of most crops including food crops (maize, common bean, wheat, sunflower, groundnuts, yams, field peas, cassava, Irish potatoes and finger-millet), cash crops (coffee, cotton and wheat), and fruits and vegetables (cabbages, tomatoes, passion fruits and onions). However, agriculture is practiced on a small scale without the use of tractors. Kapchorwa district is mountainous with poor road and transport networks, making the district inaccessible, especially during rainy seasons [14].

\subsection{Data Collection, Sources and Analysis}

Primary data collection, from 104 common bean farmers and 106 common bean traders, using structured questionnaires took place between March and June 2002. Secondary data were also used. Some of the key variables covered in the questionnaire for common bean farmers include: gender, age, education level, family size, land size, farm enterprises, acreage planted, source of technical information, amount harvested, amount sold, amount consumed place of sale and mode of transport. With respect to the questionnaire for common bean traders, the variables covered include: gender, age, education level of trader, type of market, type of marketing agent, source of bean supply, quantity bought/sold, price per unit, mode of transport, transport cost and market information. Data analyses were carried out using the Statistical Package for Social Sciences [15] and Microsoft Excel computer programs.

\subsection{Sampling of Respondents}

While the study districts were selected purposively, the surveyed common bean farmers were selected using a multistage random sampling method. Systematic random sampling procedure was used to select common bean traders. Major wholesale and retail markets in the study area were identified and selected. Retail traders and wholesalers were identified using the volume of common bean they trade on per unit time. In every market the first respondent was picked arbitrarily then the next respondent was picked by skipping one.

\subsection{Status of the Border Points Examined in the Study}

Lwakhakha: Although the Lwakhakha border point accounts for $\sim 4 \%$ of the volume of the cross border export of common bean from Uganda to Kenya, it is a wellestablished border point. However, the road to the border point is poor, leading to generally low cargo traffic, a situation that often worsens during the rainy season. This border point also has a river barrier that often overflows its banks during the rainy season, further rendering the

${ }^{1}$ Ushs means Uganda Shillings; ${ }^{2}$ Kshs means Kenya Shillings route impassable during such periods. Compared with the Lwakhakha border point, the Malaba border point is relatively busy, handling a sizeable amount of exports (including common bean) from Uganda to Kenya. This border also has a river barrier. Despite this, however, the level of trade (especially informal trade) at this point is quite significant. Busia border point has no physical barrier. The only forms of barrier are the local councils (LCs) that have instituted local taxes at the unofficial crossing points on the Ugandan side. Even though it is the least developed of the three border points, it happens to be the busiest, handling large volumes of exports of common bean (and probably other commodities) from Uganda to Kenya.

\section{Results and Discussion}

\subsection{Formal Export Procedures}

Uganda side: The Ministry of Agriculture, Animal Industry and Fisheries (MAAIF), Kampala, Uganda is the government machinery that controls the import and export of plant materials in Uganda. For any trader to export common bean and other plant materials from Uganda into Kenya, MAAIF requires 1) Plant import permit from importing country (Kenya); 2) Phytosanitary certificate (the fee of which was Ushs ${ }^{1} 2000$ or Kshs $^{2} 85$ per consignment); and 3) Letter of request for exportation (indicating the importer, the exporter and their business addresses). For the Kenya side, the Kenya plant Health Inspectorate Service (KEPHIS) is the Kenyan government agency that regulates plant imports and exports. For common bean imports to be formally allowed into Kenya or out of it, KEPHIS requires phytosanitary certificate (involving some fee) to confirm that the consignment has been inspected in Uganda and is free of pests and diseases. The other fees include: 1) Import Duty Fee (IDF) paid to customs (Kshs 5,000 per consignment), 2) Horticultural Development Authority (HCDA) levy (at the rate of Kshs $1 \mathrm{~kg}^{-1}$ of product; charged on common beans, oranges, bananas and onions), and 3) Import duty (at 3.5\% of value of produce or agricultural commodity). Countries, which are members of the Common Market for Eastern and Southern Africa (COMESA), pay 90\% less than the rate applied to import goods from non-COMESA countries. However, at the end of this survey it was established that the levies by HCDA have since been withdrawn.

\subsection{Volume of Cross-Border Common Bean Trade}

The trend in cross-border formal and informal exports of common bean from Uganda to Kenya between 1990 and 1998 is presented in Table 1. Formal export of common 
bean (Uganda to Kenya) increased from 1990 to 1991, decreased from 1992 to 1993, increased in 1994, decreased in 1995, and increased again from 1996 to 1998. The fluctuation of formal exports to Kenya was partly due to Uganda government's stringent policy of imposing lengthy documentation procedures and customs duty on common bean exports. This scenario discouraged formal cross-border bean trade and lead to most common bean traders evading formal export procedures and customs duty. With respect to the informal common bean export, it steadily increased between 1990 and 1992, decreased in 1993, increased in 1994, decreased in 1995, increased in 1996, and slightly decreased in 1997 and again in 1998. During the time when formal common bean exports were increasing from 1996 to 1998, informal common bean exports were declining. The explanation to this scenario is that the formal bean exports increase was attributed to improved trade relations, the strengthening of the East African Common market at the time and the lifting of export ban to Kenya. Overall, the total annual export of common bean from Uganda to Kenya ranged from a low value of 5,341 MT (in 1995) to a high value of 36,678 MT (1992) with a mean of $\sim 14,878$ MT across years (1990 to 1998). For the formal export of common bean, the figure ranged from a low value of 678 MT (in 1993) to 3,343 MT (1994) with a mean of $\sim 2,142$ MT. For the informal export of common bean, the figure ranged from 4,663 MT (in 1995) to 34,955 MT (1992) with a mean of 12,791 MT. Across the years while the average formal export volume of common bean (Uganda to Kenya) accounted for $~ 15 \%$ of the total common bean export, the informal export vol- ume accounted for $\sim 84 \%$ of the total. Based on 1999 estimate, of the three border points examined, Busia ranked top in volume of common bean cross border export (formal and informal) route (accounting for $\sim 70 \%$ ), followed by Malaba ( 26\%) and Lwakhakha ( 4\%) [16].

The result presented in Table 2, and based on the work of Foodnet examining formal and informal common bean export from Uganda to Kenya from four border points (including Suam) [17], further supports the supremacy of the common bean export transactions through the Busia border point compared to the other three border points. However, this 2000 data show that formal export accounted for about $55.4 \%$ of the total export of common bean from Uganda to Kenya. The situation reverted again in 2001 with informal export accounting for $~ 72 \%$ of the total common bean export volume from Uganda to Kenya [17].

The informal trade thrives due in part to the physical nature of the border points, the reluctance on the part of customs officials to record "small" transactions, the lengthy documentation procedures and the reluctance of the traders to pay "high" clearance fees. The commonly higher estimates of the informal volume of cross-border trade on common bean compared with the formal volume is an indication of serious leakage that significantly contributes to incorrect Gross Domestic product (GDP) values in Uganda and Kenya, especially the former. Strengthening of the East African co-operation initiatives will help to forestall this anomaly.

\subsection{Marketing Margins}

In Uganda, we delineated four players (middlemen,

Table 1. Trend in cross-border export of common bean: Uganda to Kenya (1990-1998).

\begin{tabular}{|c|c|c|c|c|c|}
\hline Year & Formal (Mt) & $\%$ of total & Informal (Mt) & $\%$ of total & Total (Mt) \\
\hline 1990 & 2,132 & 24.4 & 6,593 & 75.6 & 8,725 \\
\hline 1991 & 2,855 & 13.6 & 18,165 & 86.4 & 21,022 \\
\hline 1992 & 1,723 & 4.7 & 34,955 & 95.3 & 36,678 \\
\hline 1993 & 767 & 8.6 & 8,112 & 91.4 & 8,879 \\
\hline 1994 & 3,343 & 23.9 & 10,659 & 76.1 & 14,002 \\
\hline 1995 & 678 & 2.7 & 4,663 & 87.3 & 5,341 \\
\hline 1996 & 2,442 & 17.7 & 11,372 & 82.3 & 13,314 \\
\hline 1997 & 2,592 & 19.6 & 10,658 & 80.4 & 13,250 \\
\hline 1998 & 2,743 & 21.6 & 9,944 & 78.4 & 12,687 \\
\hline Total & 19,275 & 136.8 & 115,121 & 753.2 & 133,898 \\
\hline Mean & 2,142 & 15.2 & 12,791 & 83.7 & 14,878 \\
\hline
\end{tabular}

Source: Agribusiness Development Center (ADC)/IDEA project, 2000 
Table 2. Cross-border common bean exports (+value) from Uganda to Kenya (2000).

\begin{tabular}{|c|c|c|c|c|c|}
\hline \multirow{2}{*}{ Parameter } & \multicolumn{4}{|c|}{ Border point } & \multirow{2}{*}{ Total } \\
\hline & Suam & Busia & Malaba & Lwakhakha & \\
\hline Formal volume (MT) & 239 & 17,668 & 107 & 702 & 18,716 \\
\hline Formal value (US\$ Mil.) & 0.047 & 4.03 & 0.035 & 0.172 & 4.284 \\
\hline Informal volume (MT) & 378 & 11,640 & 1,733 & 1,322 & 15,073 \\
\hline Informal value (US\$ Mil.) & 0.036 & 2.20 & 0.535 & 0.313 & 3.08 \\
\hline Total volume (MT) & 617 & 29,308 & 1,840 & 2,024 & 33,789 \\
\hline Total value (US\$ Mil.) & 0.083 & 6.23 & 0.57 & 0.485 & 7.37 \\
\hline
\end{tabular}

Source: Foodnet, 2002.

commission or marketing agents, exporters of common beans to Kampala, and exporters of common bean to Kenya) in common bean marketing chain. Based on 100 $\mathrm{kg}$ bag of common bean, we evaluated the marketing margin of each of these players. The result clearly shows that all the players were making huge profits ranging from about $33 \%$ (for the commission or marketing agents), through $\sim 42 \%$ for middlemen, $\sim 45 \%$ for the exporters to Kampala to $\sim 46 \%$ for the exporters of common bean to Kenya (see Table 3). Similarly, in Kenya, we delineated three key players (middlemen, commission or marketing agents, and exporters to Nairobi) in the marketing chain of common bean and also examined their marketing margins based on $100 \mathrm{~kg}$ bag of common bean. The result is contained in the third major row of Table 3 . The average marketing margins ranged from $\sim 14 \%$ for the commission or marketing agents, through $\sim 21 \%$ for the middlemen to $\sim 25 \%$ for the exporters to Nairobi. This result shows that marketing margins made by different players in the common bean marketing chain were lower in Kenya than in Uganda. This is probably because the base price of common bean, especially if originally imported into Kenya from Uganda, was already high.

The generally high marketing margins estimated in both Uganda and Kenya, especially the former, though in excess of the marketing costs, are justified given the existing institutional, legal, and market infrastructural barriers in the study area. These barriers could have introduced some hidden transaction costs (e.g., high transport costs due to poor roads, bribes at roadblocks, taxes by local councils at unofficial crossing points) [18].

\subsection{Marketing Costs}

Results from marketing costs analyses show that both wholesalers and retailers in Uganda operated at high marketing costs, corresponding to $\sim 66 \%$ of their marketing margins (for wholesalers) and $\sim 51 \%$ of their marketing margins (retailers). The corresponding figures for Kenya were $\sim 42 \%$ for wholesalers and $\sim 38 \%$ for retailers (see Table 4). The fact that the costs of wholesalers and retailers in Uganda were $>50 \%$ of their marketing margins compared to Kenyan traders is an indication that

Table 3. Marketing margins by different players in common bean marketing chain in Uganda and Kenya\$.

\begin{tabular}{|c|c|c|c|c|c|c|c|}
\hline Country & Player & $\begin{array}{c}\text { Marketing } \\
\text { Cost (KSh/100 } \\
\text { kg bag) }\end{array}$ & $\begin{array}{c}\text { Buying price } \\
\text { (KSh/100 kg } \\
\text { bag) }\end{array}$ & $\begin{array}{c}\text { Selling price } \\
\text { (KSh/100kg } \\
\text { bag) }\end{array}$ & $\begin{array}{c}\text { Marketing } \\
\text { Margin (KSh) }\end{array}$ & $\begin{array}{l}\text { \% Mark-up of } \\
\text { Selling Price }\end{array}$ & $\begin{array}{l}\text { Marketing cost } \\
\text { as \% of Mar- } \\
\text { keting margin }\end{array}$ \\
\hline \multirow{4}{*}{ Uganda } & Middlemen & 138.60 & 697.70 & $1,162.80$ & 326.60 & 28.1 & 42.4 \\
\hline & Agents & 115.30 & 1162.80 & $1,627.90$ & 349.80 & 21.5 & 33.0 \\
\hline & $\begin{array}{c}\text { Exporters } \\
\text { to Kampala }\end{array}$ & 215.00 & 1395.30 & $2,093.00$ & 482.60 & 23.1 & 44.6 \\
\hline & $\begin{array}{c}\text { Exporters to } \\
\text { Kenya }\end{array}$ & 220.30 & 1395.30 & $2,093.00$ & 477.40 & 22.8 & 46.1 \\
\hline \multirow{3}{*}{ Kenya } & Middlemen & 176.50 & $1,000.00$ & $2,000.00$ & 823.50 & 41.2 & 21.4 \\
\hline & Agents & 125.75 & $2,000.00$ & $3,000.00$ & 874.25 & 29.1 & 14.4 \\
\hline & $\begin{array}{l}\text { Exporters } \\
\text { to Nairobi }\end{array}$ & 394.90 & $3,000.00$ & $4,600.00$ & $1,205.10$ & 26.2 & 24.5 \\
\hline
\end{tabular}

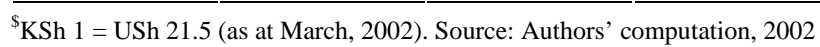




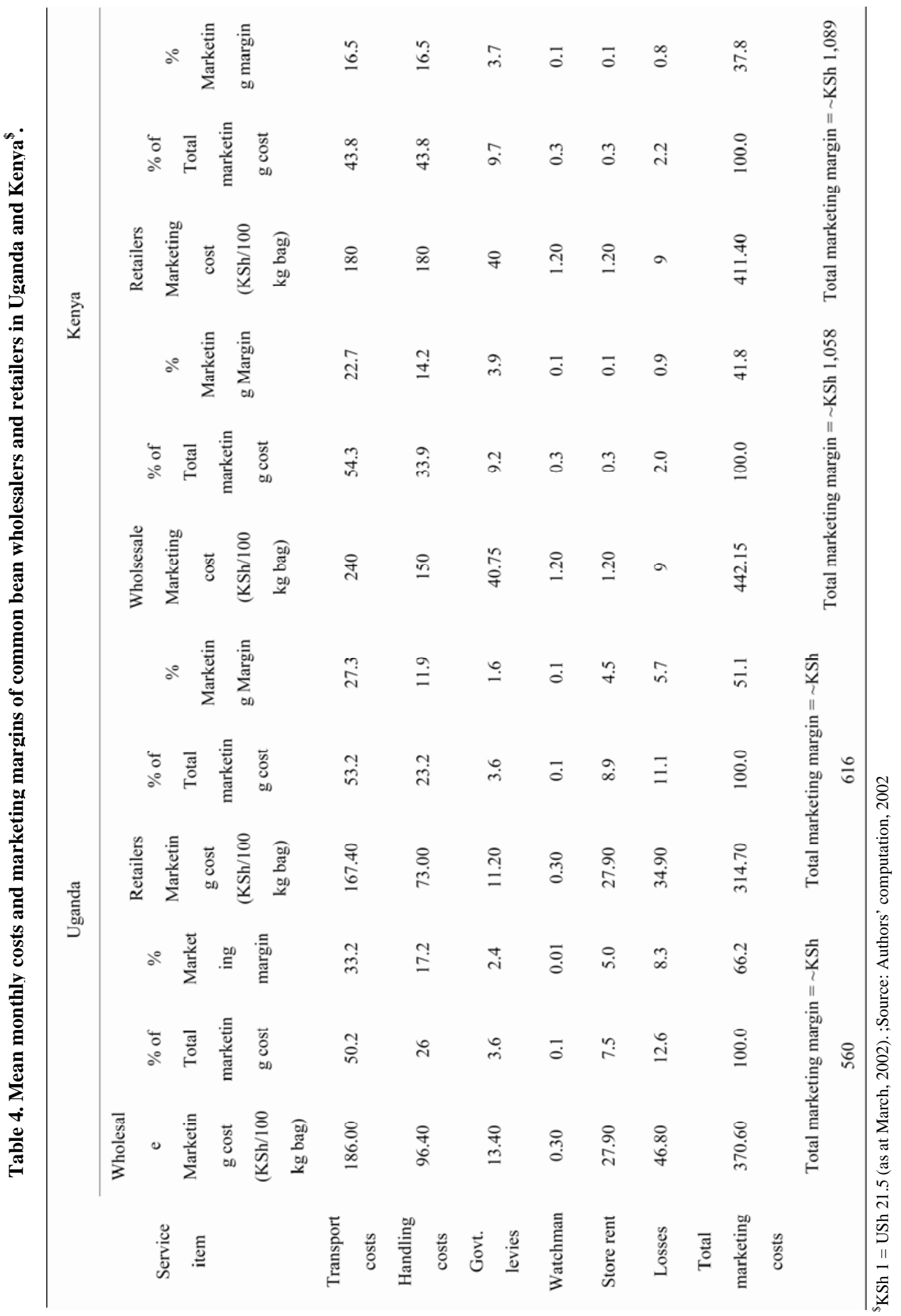

Ugandan traders operated at a higher level of efficiency than Kenyan traders. However, it is important to note that the marketing margins earned by the traders of common bean in Kenya and Uganda were in excess of the transfer costs of common bean. In Uganda, the highest margins (in monetary terms) were earned by the traders who sold 
common bean to Kampala. This was, however, only slightly $(\sim 1.1 \%)$ higher than the margins earned by the traders who exported common beans to Kenya (through the various borders) (see Table 3). Similarly, their counterparts in Kenya operated at high marketing margins (in monetary terms), with the traders exporting common bean to Nairobi earning the highest margins (see Table 3). The middlemen and agents in both Uganda and Kenya who did not export common bean also earned substantial amounts of marketing margins in the domestic market. Although they earned less margins than the exporters, the costs of the middlemen and marketing or commission agents in Uganda and Kenya were the lowest. In Uganda, these accounted for only $\sim 42 \%$ of the marketing margins for middlemen and for only about 33\% of the marketing margins for the marketing agents. The corresponding figures for Kenya were $\sim 21 \%$ of the marketing margins for the middlemen and $\sim 14 \%$ of the marketing margins for the marketing or commission agents (see Table 3). Retailers in both Kenya and Uganda operated at higher marketing margins than wholesalers.

\subsection{Price Spread}

The price of common bean in the study area varied from outlet to outlet due to differences in handling services provided by various outlets. While the average price per $2 \mathrm{~kg}$ tin measure (gorogoro) of common beans was $\sim$ Kshs 33 in rural areas of Uganda, it was $\sim$ Kshs 56 in the urban markets. The corresponding figures were $\sim$ Kshs 50 in the rural areas of Kenya and $\sim$ Kshs 60 in urban areas. A summary of the price spread with transfer costs of common bean in eight markets each in Uganda and Kenya is presented in Table 5. Changes in consumer prices are assumed to have only a small effect on the marketing costs of products, and that changes in trade margins at a time when retail prices are changing are the result of changes in profit margins rather than in marketing costs. If however, profit margins also remain relatively stable, it indicates that traders pass on consumer price changes fully to the producers. Besides, they are not in a position to use increases in demand to expand their profit margins. The gross farm-retail marketing margins (spreads) in various markets in Uganda and Kenya have been shown in Table 6. It shows price differentials ranging from $\sim 33 \%$ (for Kapchorwa and Sironko markets) to $\sim 53 \%$ (for Nyalit market) in Uganda and price differentials ranging from $\sim 17 \%$ (for Kocholia market) to $\sim 33 \%$ (for Malakisi market) in Kenya. These figures support the argument that the buyers dictate the prices at which farmer's farm produce are sold. The transfer costs do not approximate the price difference between rural markets and urban markets in Uganda and
Kenya as shown in Figure 1 and Figure 2. Traders, therefore, made profits far in excess of the transfer costs (abnormal profits). This could be due to poor market information and hidden costs due to barriers to entry into the common bean trade. Marketing margin analysis indicated that an unduly high proportion of the consumers' money is accounted for by profits accruing to traders particularly wholesalers. Furthermore, the high marketing margins are not compensated for by efficient distribution, proper presentation and methods of handling and hygiene standards in common bean markets. The producers' low share of the retail price could be aggravated by the problem of instability of common bean prices at the farm level as compared to the retail level. The direct delivery of common bean to retailers' premises coupled with low bargaining power raises the farmer's vulnerability to low prices in the exchange exercises.

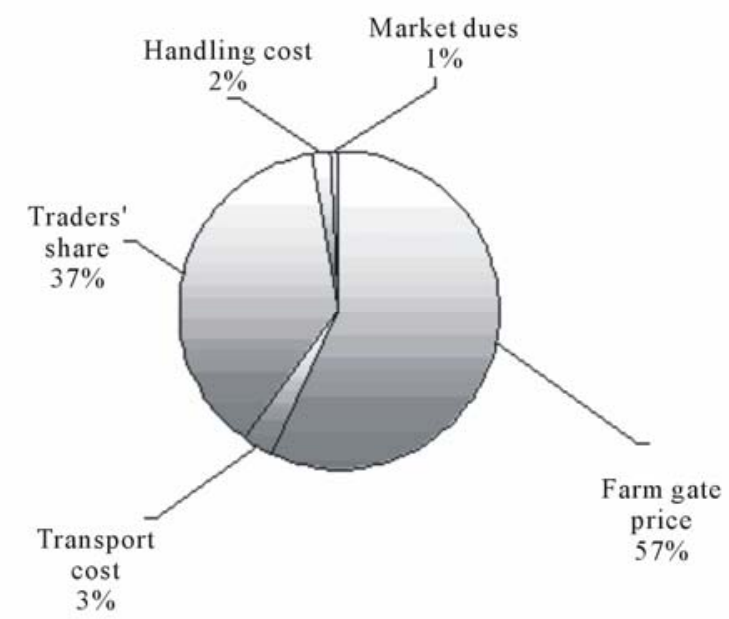

Figure 1. Proportion of the consumer spending accounted for by the market participants at different stages of the marketing system in Uganda.

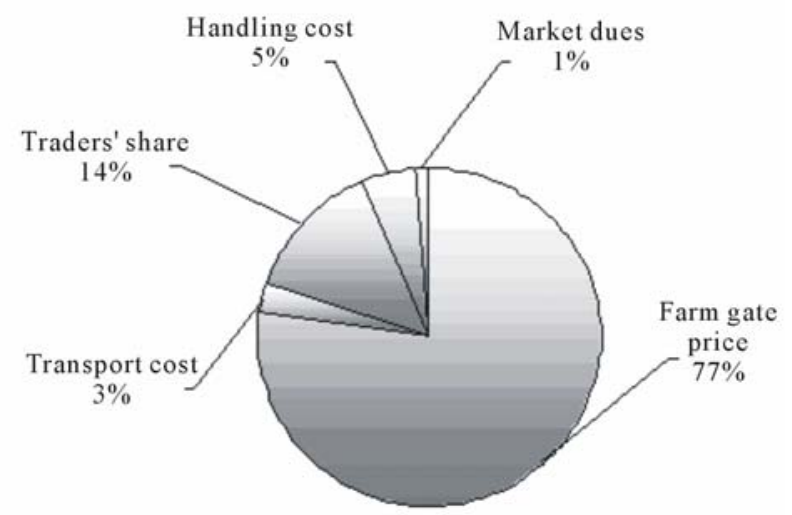

Figure 2. Proportion of the consumer spending accounted for by the market participants at different stages of the marketing system in Kenya. 
Table 5. Common bean price (KSh per $100 \mathrm{~kg}$ bag) spread in Kenya and Uganda .

\begin{tabular}{|c|c|c|c|c|c|c|c|}
\hline Country & Market & $\begin{array}{l}\text { Farm gate } \\
\text { Price }\end{array}$ & Transport cost & $\begin{array}{c}\text { Market } \\
\text { dues }\end{array}$ & $\begin{array}{c}\text { Handling } \\
\text { costs }\end{array}$ & $\begin{array}{l}\text { Traders' } \\
\text { Margin }\end{array}$ & $\begin{array}{c}\text { Consumer retail price } \\
\text { - Mbale }\end{array}$ \\
\hline \multirow[t]{9}{*}{ Uganda } & & Kshs & Kshs & Kshs & Kshs & Kshs & \\
\hline & Bukwa & 1395 & 140 & 23 & 65 & 1167 & 2790 \\
\hline & Nyalit & 1302 & 116 & 23 & 65 & 1284 & 2790 \\
\hline & Mutyoru & 1628 & 93 & 23 & 65 & 981 & 2790 \\
\hline & Kapchorwa & 1861 & 93 & 23 & 42 & 772 & 2790 \\
\hline & Bulegeni & 1628 & 93 & 23 & 42 & 1005 & 2790 \\
\hline & Muyembe & 1395 & 70 & 23 & 42 & 1261 & 2790 \\
\hline & Buyaga & 1628 & 70 & 23 & 42 & 1028 & 2790 \\
\hline & Sironko & 1861 & 47 & 23 & 42 & 819 & 2790 \\
\hline \multirow[t]{9}{*}{ Kenya } & & Kshs & Kshs & Kshs & Kshs & Kshs & Kshs \\
\hline & Angurai & 2,000 & 180 & 40 & 175 & 605 & 3,000 \\
\hline & Kocholia & 2,500 & 100 & 40 & 170 & 190 & 3,000 \\
\hline & Malaba & 2,500 & 80 & 40 & 145 & 235 & 3,000 \\
\hline & Adungosi & 2,500 & 70 & 40 & 95 & 295 & 3,000 \\
\hline & Malakisi & 2,000 & 130 & 40 & 145 & 685 & 3,000 \\
\hline & Chwele & 2,200 & 80 & 40 & 165 & 515 & 3,000 \\
\hline & Mayanja & 2,300 & 60 & 40 & 165 & 435 & 3,000 \\
\hline & Kanduyi & 2,500 & 30 & 40 & 145 & 285 & 3,000 \\
\hline
\end{tabular}

${ }^{\$}$ Kshs 1 = Ushs 21.5 (March, 2002).;Source: Authors’ computation, 2002.

Table 6. Common bean selling price/100 kg bag and related margins in Kenya and Uganda.

\begin{tabular}{|c|c|c|c|c|c|c|c|}
\hline $\begin{array}{l}\text { Ugandan } \\
\text { Markets }\end{array}$ & Farm (pf) & $\begin{array}{l}\text { Wholesale } \\
\text { (pw) }\end{array}$ & $\begin{array}{l}\text { Retail } \\
\text { (pr) }\end{array}$ & $\begin{array}{l}\text { Farm- } \\
\text { Retail } \\
\text { Spread } \\
\text { (pr-pf) }\end{array}$ & Farmers' share & $\begin{array}{c}\text { Wholsesale/Retail } \\
\text { Spread }\end{array}$ & $\begin{array}{c}\text { Wholesalers' } \\
\text { Share }\end{array}$ \\
\hline & Kshs & Kshs & Kshs & Kshs & $\%$ & pr-pw & $\%$ \\
\hline Bukwa & 1395 & 2090 & 2790 & 1395 & 50.0 & 700 & 75.0 \\
\hline Nyalit & 1300 & 1860 & 2790 & 1490 & 46.7 & 930 & 66.7 \\
\hline Mutyoru & 1630 & 2330 & 2790 & 1160 & 58.3 & 460 & 83.3 \\
\hline Kapchorwa & 1860 & 2330 & 2790 & 930 & 66.7 & 460 & 83.3 \\
\hline Bulegeni & 1630 & 2330 & 2790 & 1160 & 58.3 & 460 & 83.3 \\
\hline Muyembe & 1395 & 2090 & 2790 & 1395 & 50.0 & 700 & 75.0 \\
\hline Buyaga & 1630 & 2330 & 2790 & 1160 & 58.3 & 460 & 83.3 \\
\hline Sironko & 1860 & 2330 & 2790 & 930 & 66.7 & 460 & 83.3 \\
\hline $\begin{array}{l}\text { Kenyan } \\
\text { Markets }\end{array}$ & Kshs & Kshs & Kshs & Kshs & $\%$ & pr-pw & $\%$ \\
\hline Angurai & 2000 & 2500 & 3000 & 1000 & 66.7 & 500 & 83.3 \\
\hline Kocholia & 2500 & 2700 & 3000 & 500 & 83.3 & 300 & 90.0 \\
\hline Malaba & 2500 & 2700 & 3000 & 500 & 83.3 & 300 & 90.0 \\
\hline Adungosi & 2500 & 2700 & 3000 & 500 & 83.3 & 300 & 90.0 \\
\hline Malakisi & 2000 & 2500 & 3000 & 1000 & 66.7 & 500 & 83.3 \\
\hline Chwele & 2200 & 2600 & 3000 & 800 & 73.3 & 400 & 86.7 \\
\hline Mayanja & 2300 & 2700 & 3000 & 700 & 76.7 & 300 & 90.0 \\
\hline Kanduyi & 2500 & 2700 & 3000 & 500 & 83.3 & 300 & 90.0 \\
\hline
\end{tabular}

${ }^{\$}$ Kshs 1 = Ushs 21.5 (March 2002).;Source: Computation from Table 5. 
Table 7. Common bean marketing costs in primary markets (Ksh/100 kg bag).

\begin{tabular}{ccccc}
\hline Cost Item & Kapchorwa (Kshs) & Mbale (Kshs) & Busia (Kshs) & Bungoma (Kshs) \\
\hline Bagging materials & 4.20 & 3.00 & 6.00 & 6.00 \\
Labour costs & - & 18.60 & 37.20 & 37.20 \\
Weighing costs & - & 2.30 & - & - \\
Transport (farm gate to primary market) & 23.30 & 83.70 & 83.70 & 33.70 \\
Market dues/local tax & 4.65 & 13.95 & 37.20 & 37.20 \\
TOTAL & 32.20 & 121.55 & 164.10 & 164.10 \\
\hline
\end{tabular}

${ }^{\$}$ Kshs 1 = Ushs 21.5 (March 2002).; Source: Author’s Computation, 2002.

Table 8. Common bean marketing Costs in secondary markets (Ksh/100 kg bag).

\begin{tabular}{|c|c|c|c|c|}
\hline Cost Item & Kapchorwa (Ksh) & Mbale (Ksh) & Busia (Ksh) & Bungoma (Ksh) \\
\hline Bagging materials & 5.10 & 5.35 & 28.40 & 28.40 \\
\hline Weighing cost & 1.20 & 4.70 & - & - \\
\hline Labour costs & 23.30 & 18.60 & 37.20 & 37.20 \\
\hline Storage costs & 2.80 & - & 1.40 & 1.40 \\
\hline Transport (rural to urban market) & 69.80 & 46.50 & 46.50 & 46.50 \\
\hline Losses & 20.90 & - & - & - \\
\hline Trading License & 0.40 & 0.40 & 0.70 & 0.70 \\
\hline Security & - & - & 2.80 & 2.80 \\
\hline Local tax & - & - & - & - \\
\hline TOTAL & 123.50 & 75.55 & 117.00 & 117.00 \\
\hline
\end{tabular}

${ }^{\$}$ Kshs 1 = Ushs 21.5 (March 2002).; Source: Author’s Computation, 2002.

\subsection{Government Levies}

Government levies exist in form of taxes that the traders pay as market dues and trading license. In Uganda, on the average, primary market traders incurred more expenses in government levies (in form of trade license) than terminal traders (see Tables 7 and 8). In rural areas of both Uganda and Kenya, while primary market traders were paying market fees based on the quantities offered for sale, the urban market traders were paying a daily uniform fixed market fee, not based on sales stock (Tables 7 and 8). The source of these disparities can be traced to different methods used by government agencies in different areas use to collect these revenues. This method was particularly undesirable to primary market traders as it has the effect of raising their unit costs.

\subsection{Transportation of Common Bean: Farm to Market}

Farmsteads located in areas with limited access to commercial motor vehicles could hardly market their common beans. Incidentally, most of the areas producing common bean in significant quantities were not along tarmac roads. Besides, the distance from such high common bean producing areas to the terminal markets (where most produce was sold) ranged from $0.2 \mathrm{~km}$ to 82 $\mathrm{km}$. Bicycles were the most important means of transporting common bean from farm gate to rural markets or to the stores of the commission or market agents. With respect to transporting common bean from rural to urban markets, pick-up vans were most commonly used, especially when medium quantities were involved. Lorries were often used to transport large quantities of common bean to the final destinations, especially when these are located outside the district of origin of the consignments or outside the country. Our estimate shows that $58 \%$ of the surveyed common bean traders in Kenya and Uganda transported their common bean stock to distances of 15 to $800 \mathrm{~km}$. About $49 \%$ of these traders used motor vehicles for this. At the retail level head load, wheelbarrows, and donkeys were widely used in transporting common bean in Kenya and Uganda, especially where the distances involved were short.

In Uganda the cost of transporting a $100 \mathrm{~kg}$ bag of common bean by wholesalers accounted for about 50\% 
of the total marketing costs. The corresponding figure for Kenya was about $54 \%$. The retailers' average transport cost in Uganda accounted for $~ 53 \%$ of the total marketing cost. The corresponding figure for Kenya was $\sim 44 \%$ (Table 4). As expected, common bean traders noted that the problems of high cost of transport were more during rainy seasons (due to poor road conditions) compared with during the dry seasons. The high cost of transport experienced by common bean traders in both Uganda and Kenya reflects the poor road infrastructure in most parts of East Africa. The same poor road infrastructure forestalls effective competition amongst agricultural commodity transport providers. Transport charges were mainly based on distance traveled and mode of transport.

\section{Conclusions}

The marketing margins earned by traders in Kenya and Uganda, though in excess of transfer costs were justified. This is because of the high transport costs they incur as a result of the poor road infrastructure and weak trade institutions. Low levels of efficiency, contributed to largely by high transport costs, exist in the study area due to market imperfections. The price differentials between rural and urban markets could be attributed to scarcity of the product in urban areas leading to demand most often exceeding supply. Inefficient pricing mechanisms among spatially separated markets were common in the study area. High price differentials among markets were more than accounted for by transfer costs between markets and could be attributed to poor market information and hidden costs due to barriers to entry in the bean trade. However, there is potential in cross-border bean trade between Kenya and Uganda that could be exploited through regional co-operation.

\section{Recommendations}

Following the outcome of this study, the following recommendations could be made:

1) Necessary road infrastructure should be created, including regular maintenance of the existing roads, in common bean producing districts of Kenya and Uganda. This is critical to engender competition among transport providers and bring about the required efficiency in the marketing system of common bean in the two countries.

2) Local authorities should construct cheap market storage facilities which are appropriately located within the open air markets in order to reduce the trader's handling and other marketing costs. This will also generate extra revenues in form of stall hiring charges.

3) Policies to strengthen regional co-operation and eliminate trade obstacles (e.g., non-tariff and institutional barriers) must be put in place to reduce the transaction cost in common bean marketing.

\section{Acknowledgements}

The authors wish to sincerely thank ECABREN/CIAT for funding this study.

\section{REFERENCES}

[1] C. S. Wortmann, R. A. Kirkby, C. K. A. Eledu and D. J. Allen, "Atlas of Common Bean (Phaseolus vulgaris L.) Production in Africa," CIAT, Cali, Colombia (Publication No. 297), 1998.

[2] ECABREN, "Towards the Development of Market-Driven Research Framework,” May 2000.

[3] GOK, “Government of Kenya Economic Survey 1997," Central Bureau of Statistics, Nairobi, 1998.

[4] R. M. Muasya, “Crop Physiological Analysis of Seed Quality Variation in Common Beans (Phaseolus vulgaris L.),” Ph.D. Thesis, Wageningen University, The Netherlands, 2001.

[5] L. W. Mauyo, J. R. Okalebo, R. A. Kirkby, R. Buruchara, Ugen, M. Mengist, C. T. Anjichi and R. O. Musebe, “Technical Efficiency and Regional Market Integration of Cross-Border Bean Marketing in Western Kenya and Eastern Uganda,” Journal of Business Management, Vol. 1, No. 4, 2007, p. 78.

[6] M. O. Odhiambo, “Opportunities, Constraints and Possible Solutions to Improve the Access of Uganda Maize and Beans to the Kenyan Market,” International Science and Technology Institute, in Association with High Value Hortculture Plc, Washington D.C. and Uxbridge, 1994.

[7] C. Ackello-Ogutu and P. Echessah, "Unrecorded CrossBorder Trade between Kenya and Uganda: Implications for Food Security,” Technical Paper, No. 59, USA- ID Washington D.C, 1997.

[8] M. Wandel and G. Holmboe-Ottesen, "Food Availability and Nutrition in Seasonal Perspective: A Study from Region in Tanzania,” HUM Eco, No. 20, 1992, pp. 89-107.

[9] R. A. Kirkby, Proceedings of Workshop on Bean Research in Eastern Africa, Mukono, Uganda, 22nd-25th June 1987, CIAT African Workshop Series, No. 2, 1987.

[10] S. David, "Beans in the Farming System and Domestic Economy of Uganda. A Tale of Two Parishes,” Network on Bean Research in Africa, Occasional Publications Series, No. 28, CIAT, Kampala, 1999.

[11] NARO, Annual Report, Entebbe, Uganda, 2000.

[12] GOK, Bungoma District Development Plan, Government Printers, Nairobi, 1997(a).

[13] GOK, Busia District Development Plan, Government Printers, Nairobi, 1997(b).

[14] O. R. Mugisha, "Uganda Districts, Information Handbook,” Fountain Publishers, Kampala, Uganda, 1998.

[15] SPSS (Statistical Package for Social Sciences), Statistical Package for Social Sciences Release 11.0, Prentice Hall, Chicago, 2002. 
[16] ADC/IDEA Project, "Monthly Bean Prices 2001- 2002," Kampala. Baert, T. G. "Country Report-Great Lakes: Burundi,” In: J. B. Smithson, Proceedings of a Workshop on Bean Varietal Improvement in Africa, Maseru, Lesotho 30th January-2nd February 1989, CIAT African Wor- kshop Series, No. 4, 1989, p. 137.
[17] Foodnet, “Cross-border Statistics, 2001-2002,” Kampala.

[18] L. W. Mauyo, J. R. Okalebo, R. A. Kirkby, R. Buruchara, M. Ugen and R. O. Musebe, "Legal and Institutional Constraints to Kenya-Uganda Cross-Border Bean Marketing," African Journal of Agricultural Research, Vol. 2, No. 11, 2007, p. 582. 